\title{
Effect of supersulphated cement on sulfate attack of cement mortar
}

\author{
Niu quanlin ${ }^{1, a^{*}}$ zhang rui ${ }^{2, b}$ \\ ${ }^{1}$ school of material science and engineering, Shandong university of technology, Zibo, Shandong \\ 255049, P.R .China \\ ${ }^{2}$ Library of shandong university of technology, Zibo, Shandong 255049, P.R .China \\ aniuql00@sdut.edu.cn
}

Keywords: Supersulphated cement; sulfate Attack; ettringite; corrosion coefficient

Abstract: Supersulphated cement with 5\%--10\% of clinker, $15 \%$ of gypsum, $75-80 \%$ of slag was prepared, sulfate attack on mortars blended with ordinary portland cement and supersulphated cement was examined according to ASTM C1012 and the Chinese nation standard GB2420. It is shown that supersulphated cement exhibits excellent durability in sulfate attack environment, the 15-week expansion (ASTM C1012) decreased to less than 0.06\%, 3-month corrosion coefficient (GB2420) of the SSC mortars immersed in $\mathrm{Na}_{2} \mathrm{SO}_{4}$ solution was $50 \%$ higher than that of the ordinary portland cement.

\section{Introduction}

Deterioration of drainage pipeline due to Sulfate attack is a composite process including both physical and chemical reactions. physical attack is due to the reversible change of anhydrous sodium sulfate (thenardite) into decahydrate (mirabilite) accompanied by large crystallization pressure and the subsequent deterioration [1], chemical attack of domestic sewage $\mathrm{H}_{2} \mathrm{~S}$ related sulfate is the result of both acid corrosion and ettringite expansion.

Formation of ettringite through reaction between $\mathrm{C}_{3} \mathrm{~A}$ and $\mathrm{CaSO}_{4}$ brings inhomogeneous expansion in the hardened cement stone, as expansion stress is much bigger than the tensile strength of cement and concrete, soften and corrosion happens.

Replacement of cement with admixtures such as ground granulated blast-furnace slag (GGBS), fly ash (FA), metakaoline and silica fume were found effective in improving the sulfate resistance of concrete [2-4], concrete incorporating 45-72\% of GGBFS were also perfectly preserved after 10.5 years of immersion in $3000 \mathrm{mg} / \mathrm{SO}_{4}{ }^{2-}$ solution, while the controlled specimens exhibit different extent of deterioration regardless of the $\mathrm{C}_{3} \mathrm{~A}$ content $(3.5 \sim 12.3 \%)$ [5].

Incorporation of admixtures in portland cement relives the expansion pressure by dilution effect and pozzolanic effect. Dilution of $\mathrm{C}_{3} \mathrm{~A}$ content decreases the content of ettringite, while pozzolanic effect decreases the $\mathrm{Ca}(\mathrm{OH})_{2}$ content in hydration products, densification of cement paste through pozzolanic reaction is also helpful because harmful ions could not penetrate into concrete easily in densified cement paste.

Supersulphated cement (SSC) made with $10 \%-20 \%$ of gypsum is widely accepted as sulfate attack resistant material. As the complete reaction between $\mathrm{CaSO}_{4}$ and $\mathrm{C}_{3} \mathrm{~A}$ at early age, no additional reaction happens when the cement stone is subjected to sulfate environment. As clinker or lime content is very small in $\mathrm{SSC}$, little $\mathrm{Ca}(\mathrm{OH})_{2}$ was found in hydration products, which is also beneficial for mortar and concrete to resistant sulfate attack. 
In this paper, expansion ratio and corrosion coefficient of cement mortar specimens were examined according to ASTM C1012) and GB2420 respectively, visual examination of concrete immersed in $\mathrm{Na}_{2} \mathrm{SO}_{4}$ solution were also visually examined for comparison.

\section{Experimental}

Materials. P.O42.5 cement, GGBS and gypsum were used, chemical composition of the materials was shown in Table 1.

Table 1 Composition of the materials used in the test

\begin{tabular}{cccccccccc}
\hline \multirow{2}{*}{ materials } & \multicolumn{8}{c}{ Chemical composition } \\
\cline { 2 - 10 } & $\mathrm{SiO}_{2}$ & $\mathrm{Al}_{2} \mathrm{O}_{3}$ & $\mathrm{Fe}_{2} \mathrm{O}_{3}$ & $\mathrm{CaO}$ & $\mathrm{MgO}$ & $\mathrm{SO}_{3}$ & $\mathrm{~K}_{2} \mathrm{O}$ & $\mathrm{Na}_{2} \mathrm{O}$ & LOI \\
\hline Cement P.O42.5 & 20.88 & 4.72 & 3.10 & 63.26 & 3.43 & 1.85 & 0.61 & 0.28 & 2.04 \\
Blast furnace slag & 36.33 & 10.64 & 0.79 & 38.51 & 8.11 & 0.14 & 0.51 & 0.26 & $/$ \\
gypsum & $/$ & $/$ & $/$ & 40.71 & $/$ & 56.6 & $/$ & $/$ & 0.25 \\
\hline
\end{tabular}

Test details. Three specimens were prepared: supersulphated cement, ordinary portland cement (P.O42.5), and 50\% P.O42.5 +50\%GGBS.

Expansion ratio of the mortars was examined according to ASTM C1012, mix proportion was shown in table.2. The corrosion coefficient or ratio of flexual strength of mortar was tested according to Chinese standard GB 2420, mix proportion was given in table.3.

Table 2. Mix proportion of the cement and mortars according to ASTM C1012

\begin{tabular}{ccccc}
\hline specimen & P.O42.5 & admixtures & Standard sand & water \\
\hline P.O 42.5 & $1250 \mathrm{~g}$ & $/$ & $3438 \mathrm{~g}$ & $606 \mathrm{ml}$ \\
SSC2 & $62.5 \mathrm{~g}$ & $\begin{array}{c}\text { GGBS 468.75g } \\
\text { gypsum 93.75g }\end{array}$ & $3438 \mathrm{~g}$ & $606 \mathrm{ml}$ \\
\hline
\end{tabular}

Table 3. The mix proportion of the mortar specimens according to GB2420

\begin{tabular}{ccccc}
\hline specimen & P.O 42.5 & Mineral powder & water & Standard sand \\
\hline K1 & $100 \mathrm{~g}$ & $/$ & $50 \mathrm{ml}$ & $250 \mathrm{~g}$ \\
$\mathrm{~K} 2$ & $50 \mathrm{~g}$ & GGBS $50 \mathrm{~g}$ & $50 \mathrm{ml}$ & $250 \mathrm{~g}$ \\
$\mathrm{SSC} 1$ & $10 \mathrm{~g}$ & $\begin{array}{c}\text { GGBS } 75 \mathrm{~g} \\
\text { gypsum } 15 \mathrm{~g}\end{array}$ & $50 \mathrm{ml}$ & $250 \mathrm{~g}$ \\
$\mathrm{SSC} 2$ & $5 \mathrm{~g}$ & $\begin{array}{c}\text { GGBS } 80 \mathrm{~g} \\
\text { gypsum } 15 \mathrm{~g}\end{array}$ & $50 \mathrm{ml}$ & $250 \mathrm{~g}$
\end{tabular}

Corrosion coefficient is the ratio of the flexual strength of the mortars immersed in water to that immersed in $3 \% \mathrm{Na}_{2} \mathrm{SO}_{4}$ solution at curing age of 3 months.

By the way, $100 \times 100 \times 100 \mathrm{~mm}$ concrete specimens with binder mix proportion as table. 3 were immersed in $5 \% \mathrm{Na}_{2} \mathrm{SO}_{4}$ solution for 3 months, specimens were visually examined.

\section{Result and discussion}

Expansion ratio of mortar specimens. Though not consistent with field investigation in some respects [6], ASTM C1012 is an important method to examine the sulfate resistance of cement 
containing mineral admixtures. The test result was shown in fig.1.

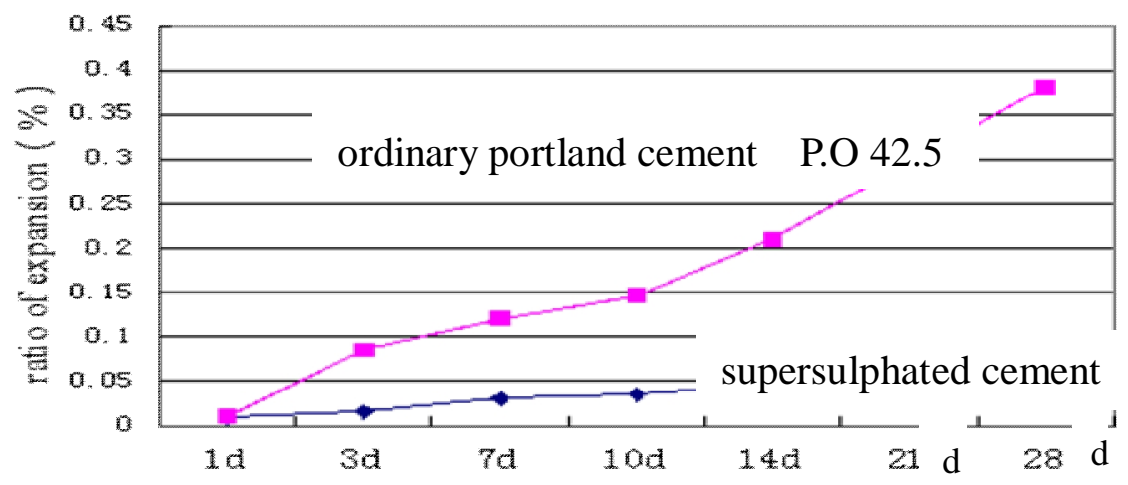

Fig.1. Expansion of mortar specimens

It is seen in fig. 1 that supersulphated cement mortars exhibits excellent volume stability in 5\% sodium sulfate solution, with expansion rate of less than $0.06 \%$, while the controlled specimen prepared with P.O. 42.5 cement was over $0.16 \%$ after 15 weeks of immersion.

Expansion of the mortars was generally considered as the result of ettringite formation accompanied by volume increase:

$$
6 \mathrm{Ca}^{2+}+2 \mathrm{Al}(\mathrm{OH})_{4}{ }^{-}+4 \mathrm{OH}^{-}+3 \mathrm{SO}_{4}{ }^{2-}+26 \mathrm{H}_{2} \mathrm{O} \rightarrow \mathrm{Ca}_{6}\left[\mathrm{Al}(\mathrm{OH})_{6}\right]_{2} \cdot 3 \mathrm{SO}_{3} \cdot 26 \mathrm{H}_{2} \mathrm{O} \quad 1
$$

It is known in equation 1 that formation of ettringite was determined by concentration of $\mathrm{Ca}^{2+}$, $\mathrm{Al}(\mathrm{OH})_{4}{ }^{-}$and $\mathrm{SO}_{4}{ }^{2-}$ in alkaline solution, especially the ion with minimum concentration.

For Portland cement, complete hydration of the clinker materials releases $20 \%$ to $25 \%$ of $\mathrm{Ca}(\mathrm{OH})_{2}$, therefore the $\mathrm{C}_{3} \mathrm{~A}$ content was crucial and cement with low $\mathrm{C}_{3} \mathrm{~A}$ was recommended in sulfate environment.

For supersulphated cement, there is only $5 \%$ to $10 \%$ of P.O 42.5 , most of the $\mathrm{Ca}(\mathrm{OH})_{2}$ was consumed through pozzolanic reaction to form ettringite and C-S-H gel, little free lime was left for further reaction when immersed in $\mathrm{Na}_{2} \mathrm{SO}_{4}$ solution.

Corrosion coefficient. Corrosion coefficient of the specimens K1, K2, SSC1, SSC2 was shown in fig.2.

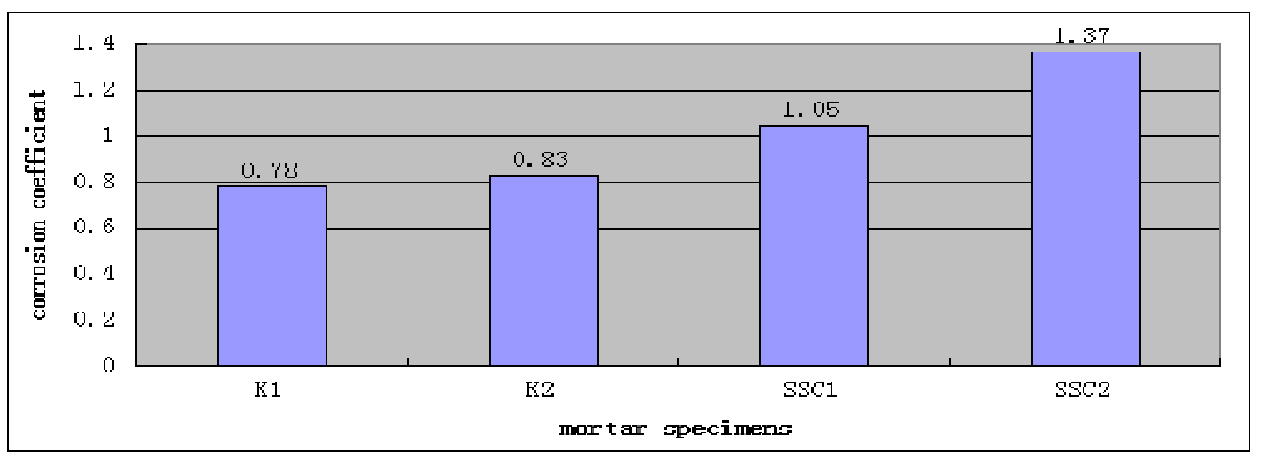

Fig.2 Corrosion coefficient of mortars at 3 months age

It is shown in fig. 2 that the value of $\mathrm{R}_{\mathrm{c}}$ for controlled specimen $\mathrm{K} 1$ blended with pure P.O42.5 cement is 0.78 , for specimen $\mathrm{K} 2$ with addition of $50 \%$ of GGBS, the $\mathrm{R}_{\mathrm{c}}$ value is 0.83 , this means incorporation of GGBS is beneficial as a result of dilution effect and pozzolanic effect.

Corrosion coefficient is used to evaluate the sulfate resistant ability of cement by comparision of the flexual strength, as flexual strength of mortar specimens is more sensible to sulfate attack 
than compressive strength, ratio of flexual strength of mortars immersed in water to that of immerse in $3 \% \mathrm{Na}_{2} \mathrm{SO}_{4}$, is defined as corrosion coefficient, $\mathrm{R}_{\mathrm{c}}, R_{c}=\frac{R_{\text {sulfate }}}{R_{\text {water }}}$.

For supersulphated cement the $\mathrm{R}_{\mathrm{C}}$ value increased from 1.03 to 1.37 , both are much better than $\mathrm{K} 1$ and $\mathrm{K} 2$. The highest $\mathrm{R}_{\mathrm{C}}$ value of SSC2 specimen with 5\% P.O42.5+80\%GGBS+15\% gypsum is 1.37 , as there is little $\mathrm{Ca}(\mathrm{OH})_{2}$ content in hydration products, both ettringite and gypsum formation is inhibited.

$100 \times 100 \times 100 \mathrm{~mm}$ concrete specimens with binder mix proportion as table. 3 was prepared, when compressive is $20 \mathrm{MPa}$, specimens were immersed in $5 \% \mathrm{Na}_{2} \mathrm{SO}_{4}$ solution for 3 months, visual examination was employed as shown in fig. 3 .

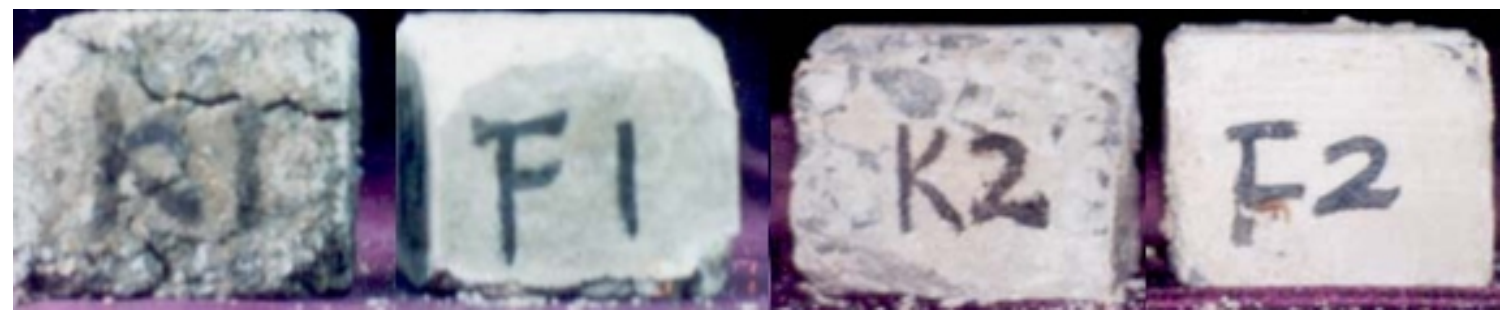

Fig. 3. Deterioration of mortars after 3 months of immersion in $5 \% \quad \mathrm{Na}_{2} \mathrm{SO}_{4}$ solution

\section{Summary}

Supersulphated cement exhibits excellent resistance to sulfate attack according to ASTM C10212 and GB 2420 test, the expansion rate in $5 \% \mathrm{Na}_{2} \mathrm{SO}_{4}$ solution is less than $0.06 \%$, corrosion coefficient is 1.05 for SSC1 and 1.37 for SSC 2, for concrete drainage pipeline subjected to $\mathrm{H}_{2} \mathrm{~S}$ and domestic sewage related sulfate attack, application of supersulphated cement is helpful for the improvement of concrete durability.

\section{References:}

[1]. Adam Neville, The confused world of sulfate attack on concrete, Cement and Concrete Research 34 (2004) 1275-1296.

[2]. K.Torii, K.Taniguchi, M.Kawamura, Cement and concrete research, 25(1995)4:pp759-768.

[3].E.F.Irassar, A.Di Maio, O.R.Batic. sulfate attack on concrete with mineral admixtures. Cement and concrete research, 26(1996)1:pp113-123.

[4].. Karthik H. Obla, Russell L. Hill, Michael D.A Thomas, et al. properties of concrete containing ultrafine fly ash. ACI materials journal, Vol.100(5):426-433.

[5]. R.Doug Hooton, John J.Emery. Sufate resistance of a Canadian slag cement. ACI materials journal, Vol.87(6) : 547 - 555.

[6]Mehta, P.K. sulfate attack on concrete. A critical review. Proc. Int. sem. Durab. Monterey, pp106-132(1993). 